\title{
Magyarországi termesztett levendula (L. angustifolia Mill., L. x intermedia (L.) Emeric) állományok antioxidáns kapacitásának és polifenol mintázatának vizsgálata
}

\section{Détár Enikő, Zámboriné Németh Éva, Szabó Dóra, Pluhár Zsuzsanna}

Szent István Egyetem, Kertészettudományi Kar, Gyógy- és Aromanövények Tanszék, 1118 Budapest, Villányi út 29-43.

A levendula fajok világszerte nagy jelentőségú illóolajos gyógynövényként ismertek, érdemes azonban figyelmet fordítani a kevéssé feltárt, fenoloid típusú vegyületeikre is. Számos irodalmi adat igazolja, hogy a levendula beltartalmi anyagainak alakulását elsődlegesen a genotípus határozza meg, azonban emellett számos környezeti tényező (termőterület, éghajlati adottságok) is befolyásolhatja. Hazánkban az elmúlt években megnövekedett az érdeklődés a levendula termesztése iránt, ugyanakkor kevés információ áll rendelkezésre a fajták beltartalmi jellemzőit illetően. Ezért kísérleteinkben 4 eltérő adottságú magyarországi termőterületről (Budapest/Soroksár, Tihany, Dörgicse, Szomód) gyűjtöttünk mintákat másodvirágzásban levő levendula állományokból 2016 októberében. Hét $L$. angustifolia és három $L$. $x$ intermedia fajta előzetes értékelésére került sor, levél és virág minták alapján. Az antioxidáns-kapacitás és az össz-polifenol tartalom meghatározása vizes kivonatokból történt, 15-18 ismétlésben. Megállapítottuk, hogy az antioxidáns-kapacitás vizsgálatakor kapott adatok korrelálnak az össz-polifenol értékekkel. A legmagasabb értékeket a hibrid levendula fajták leveleiben mértük, különösen a soroksári L. $x$ intermedia 'Judit' esetében (235,53 mg ASE/g sz.a. és 179,22 mg GSE/g sz.a.). A termőhelyek összehasonlításakor kimutattuk, hogy a Szomódon gyüjtött 'Munstead' (159,28 mg ASE/g sz.a.), 'Hidcote' (159,86 mg ASE/g sz.a.) és 'Grappenhall' (201,64 mg ASE/g sz.a.) fajták mintáiban nagyobb antioxidáns aktivitás mérhető, mint ugyanezen fajtáknál Dörgicsén. A továbbiakban szükségesnek tartjuk e vizsgálatok elvégzését nyáron, a fő virágzás időszakában, valamint a termőhelyi hatások pontosabb értékeléséhez a talaj- és időjárási tényezők elemzését is. A FRAP módszer mellett az antioxidáns kapacitás értékelését a DPPH-módszerrel is ki kívánjuk egészíteni.

Köszönetnyilvánítás: Ezúton fejezzük ki köszönetünket Dr. Demján Ildikónak a dörgicsei Levendula Major Kft. ügyvezetőjének, illetve Tóth Józsefnek, a Szomódi Levendulás vezetőjének a minták rendelkezésünkre bocsátásáért.

Témavezető: Pluhár Zsuzsanna (SZIE, Gyógy-és Aromanövények Tanszék) 